\title{
United States: The Uphill Schools' Struggle
}

\author{
Eric A. Hanushek
}

\begin{abstract}
The United States has seen generally flat performance on both international and national tests. Moreover, the achievement gaps between disadvantaged and more advantaged students have been large and constant for a half century. The remarkable aspect of these outcomes is that federal and state programs have changed significantly - considerably greater resources, added school choice, testbased accountability, and school desegregation. Because of the importance of skills for the economy, it is important that the schools improve, but there is no indication of finding the set of policies that will do this.
\end{abstract}

\section{Introduction}

Some nations have reacted strongly to international achievement results, particularly after the introduction and expansion of PISA results that began in $2000 .{ }^{1}$ The Germans were horrified with the initial results in 2000, while the Finns basked in the glory of high performance. The United States reaction was, however, at best subdued to the point of generally ignoring the results.

For those who have followed the PISA scores for the United States, there are few surprises. In terms of time trends across the subjects, the 2018 scores in mathematics and reading were not significantly changed over the entire period of PISA. The science scores were significantly better in 2018 than in 2006, but a substantial gap with the better performing nations remains.

\footnotetext{
${ }^{1}$ PISA is the Programme for International Student Assessment, conducted by the OECD (https:// www.oecd.org/pisa/).

${ }^{2}$ TIMSS is the Trends in International Mathematics and Science Study. It has been operational (with a changing group of countries) since the mid-1960s, and has been organized and run by the IEA (International Association for the Evaluation of Educational Achievement), which is an international cooperative (https://www.iea.nl/). See the summary of international tests in Hanushek and Woessmann (2011).
}

\section{E. A. Hanushek $(\bowtie)$}

Hoover Institution, Stanford University, Stanford, USA

e-mail: hanushek@stanford.edu 
The international scores on PISA and on the parallel TIMSS ${ }^{2}$ testing program did not receive much attention until the Obama administration began publicizing the 2009 results. The fact that the international testing did not receive much attention does not mean, however, that there was no prior attention to student achievement. For almost 50 years, there has been consistent testing of U.S. students, and this permits tracking changes in performance over time. For the past two decades, it has also been possible to compare performance across U.S. states.

As described below, the different testing programs-PISA, TIMSS, and the longitudinal testing within the U.S., have given very similar pictures of the performance of U.S. students. Thus, there is no U.S. PISA shock, because the results from PISA can overall be seen in the other existing programs.

The picture is remarkable: First, with some nuances, overall U.S. performance has remained virtually constant for a half century; second, gaps in achievement across socio-economic groups have also remained constant for the past half century.

If attention to schooling and if programmatic elements of schooling were also constant, we could conclude this essay now. In other words, if a stagnant system produced constant results, there would not be much to say. But that is not the case. Schooling in the United States has changed in many ways. These ways have been focused on changing the performance picture, both in overall level and in the distribution of achievement. Therefore, it is useful to consider what policy changes have taken place along with the picture of constant results.

The overall story is simple. U.S. performance on international tests has never been good. There is a general notion in society that the schools should be doing better, and, toward that end, there have been large policy changes. Yet the changes that have been taken have not led to better outcomes. Even with a general appreciation for the economic importance of educational quality, the changes that have occurred have not been effective.

This chapter begins with an overview of the performance of U.S. students as seen from both international and national tests; this includes information on the level of achievement and the distribution of performance. It then turns to a discussion of the structure and organization of U.S. schools (Sect. 3) and of the major programs of the federal government (Sect. 4) and the state governments (Sect. 5). This discussion is followed by consideration of evidence about why this performance measures important things from the standpoint of the economy (Sect. 6) and why the U.S. has done better than would be expected based on the quality of its graduates (Sect. 7). It concludes with speculation about whether the good fortune of the U.S. economy will last if the schools do not improve.

\section{Long Term Achievement Patterns}

The international testing of achievement began in 1964 with the First International Mathematics Study. Of the 11 participating countries, the U.S. ranked tenth, beating 
out Sweden. ${ }^{3}$ When the Second International Mathematics Study was conducted in 1980-82, the U.S. was in 13th place out of 17 participants-beating out Sweden, Luxemburg, Thailand, and Swaziland. Thus, it is not a surprise if a significant proportion of developed countries taking the tests outpace the U.S.

The overall trends in performance of U.S. students are easy to describe and are very consistent.

\subsection{Pattern of PISA Scores}

Since the beginning of PISA in 2000, the U.S. has been slightly above or slightly below the OECD average depending on the specific test. And it has stayed there. Figure 1 shows the performance on the separate reading, math, and science assessments of PISA. The dashed line in each panel shows the pattern of the OECD average. While some movement can be seen, the plots visually demonstrate the lack of significant movement. ${ }^{4}$

\subsection{Pattern of National Assessment of Educational Progress (NAEP) Scores}

The lack of surprise with PISA scores is easily explained by the pattern of scores on the U.S. National Assessment of Educational Progress (NAEP). This is an assessment given to a random sample of students using tests that can be linked over time. Figure 2 displays performance on the NAEP math and reading tests for students age 13 and age $17 .^{5}$ The top two lines show reading and math scores of 17 -year-olds, while the bottom two lines cover 13-year-olds. These patterns are best described as flat student performance over three to four decades - with one exception. The math performance of 13-year-olds rises significantly over the period. The puzzle, and the concern, is that higher middle school math performance does not readily translate into higher performance four years later in secondary schools. In any event, it is clear that the earlier performance improvements do not produce improved performance at the time that students are entering the labor force or further education.

\footnotetext{
${ }^{3}$ For a history of international testing along with scores on earlier tests, see Hanushek and Woessmann (2011).

${ }^{4}$ Note that the psychometric linking of the PISA scores occurred at different times for the separate subjects so that the reading series begins in 2000 , math in 2003 , and science in 2006 . The U.S. does not have reading scores for 2006 because of a problem with the testing in that year.

${ }^{5}$ The National Assessment of Educational Progress has changed over time. The original test (Long Term NAEP) began in the 1970s and considered just a national sample. In 1990, an alternate test (Main NAEP) was introduced in order to provide state representative data. The Long Term NAEP collection was stopped in 2012. All data are cross-sectional for newly constructed representative samples.
} 
U.S.

Reading Performance on PISA

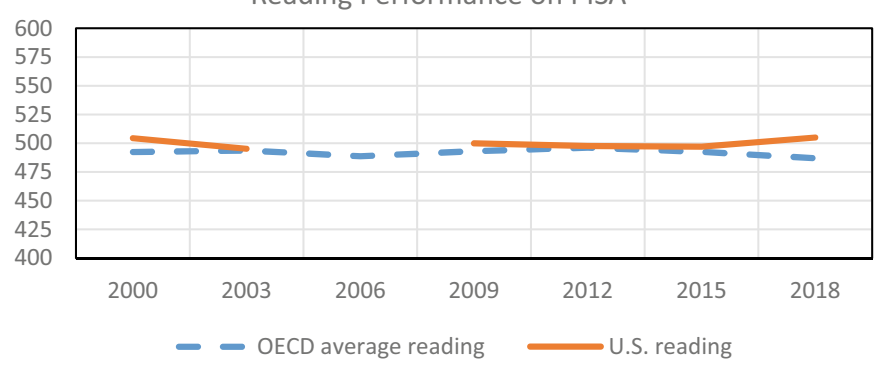

U.S. Math Performance on PISA

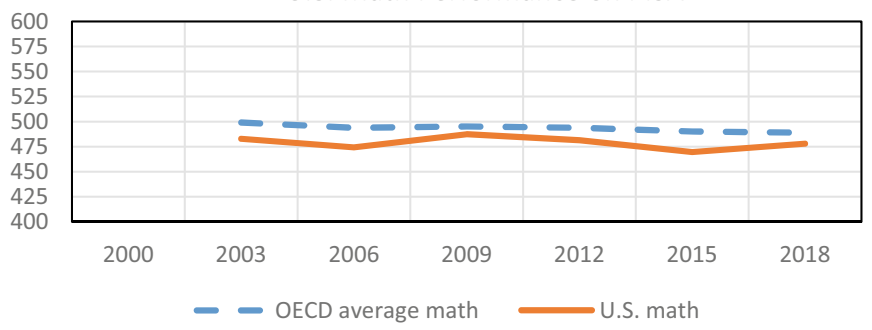

U.S. Science Performance on PISA

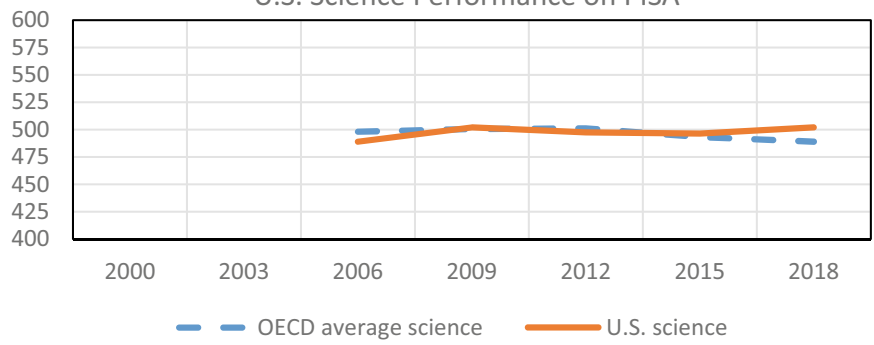

Fig. 1 United States PISA Scores, 2000-2018. Notes U.S. reading scores for 2006 unavailable because of a test administration problem. Aligned math tests begin in 2003, and aligned science tests begin in 2006. Source https://nces.ed.gov/surveys/international/ide/

\subsection{Pattern of Achievement Gaps}

Educational policy clearly has a variety of objectives, but the two recurring goals are higher overall achievement and equitable provision of education. What is a particularly important goal in most countries is using schooling and human capital investments to break the intergenerational transmission of poverty. When translated into achievement differences, this goal implies narrowing any gaps in student performance that are correlated with family socio-economic status (SES). Indeed, the U.S. has a wide range of programs (described below) that are aimed at improving the 


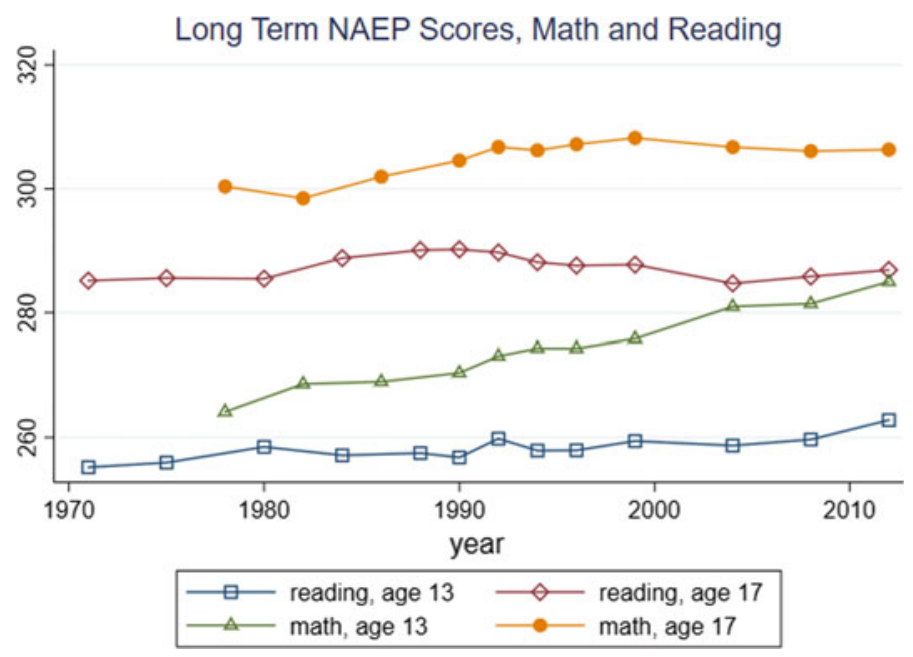

Fig. 2 Long Term NAEP Scores, Math and Reading. Source https://nces.ed.gov/nationsreportcard/

education and achievement of children from poor families. Here it is important to see what has happened to achievement gaps by SES.

Hanushek et al. (2020) combined test information from NAEP, TIMSS, and PISA with background information on the SES of each child. They then compared over time achievement of those in the top quarter of the SES distribution with those in the bottom quarter. Figure 3 shows the pattern of achievement gaps over the past half century. Achievement gaps have not changed!

After the 1954 desegregation of schools ordered in the U.S. Supreme Court decision of Brown v. Board of Education, the black-white achievement gaps narrowed until roughly 1990, but then progress stopped (Hanushek et al. 2020). The remaining gap is unacceptably large at roughly 0.9 standard deviations. This difference implies that the average black student is below the twentieth percentile of white students.

\subsection{Conclusions on Achievement}

The pattern of achievement — as seen by PISA or more broadly by NAEP —indicates little has changed over long periods of time. When broken down by SES of the family, the answer is the same-no movement over long periods of time.

To put this into perspective, it is important to see what changes in school programs and policies have occurred, because they will say something about what look to be good policies. 


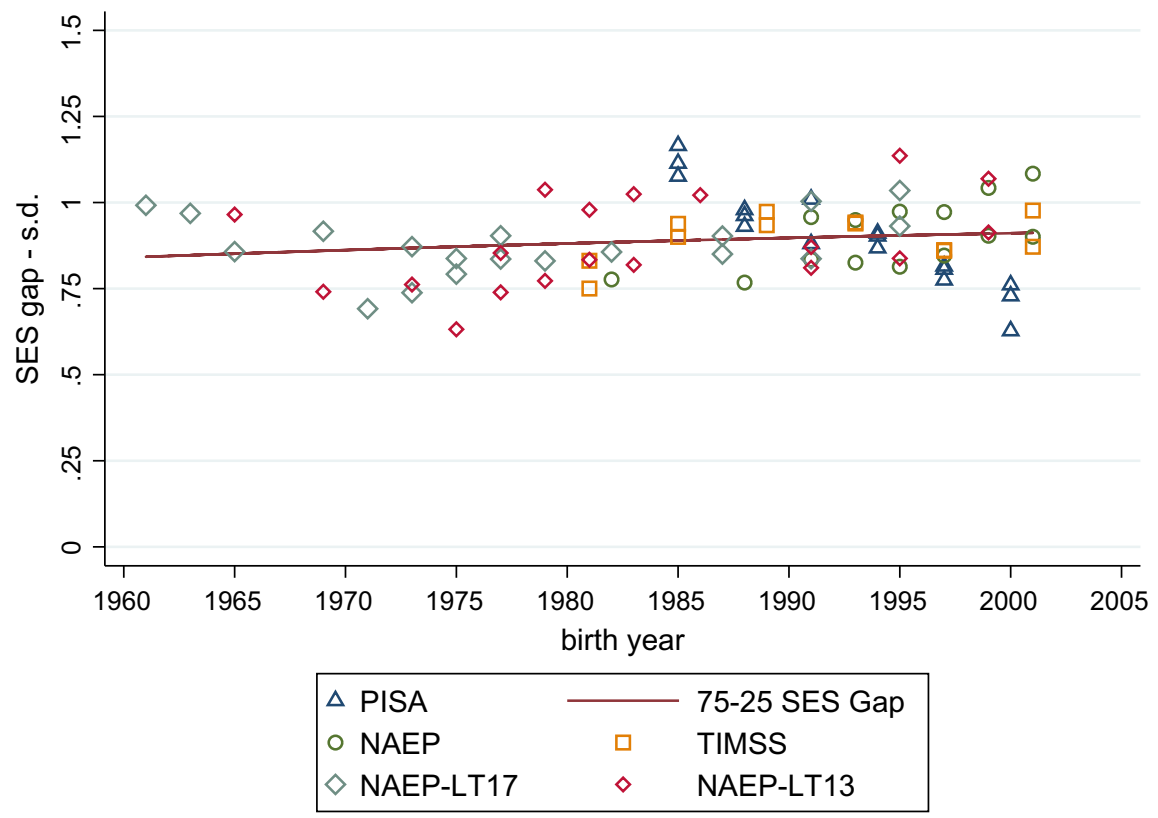

Fig. 3 Trend in the SES-Achievement Gap with Underlying Test Data, Birth Cohorts 1961-2001. Notes Achievement difference between the students in the top and bottom quartiles of the SES distribution (75-25 SES-achievement gap). The separate points are the 75-25 SES-achievement gap for the individual test administrations, and the line is the quadratic trend through the points. PISA is scores in math, reading, and science for 15-year-olds; NAEP is the Main-NAEP scores for eight graders in math and reading; TIMSS is scores in math and science for eighth graders; NAEPLT17 is the long-term trend NAEP scores in math and reading for 17-year-olds; and NAEP-LT13 is the long-term trend NAEP scores in math and reading for 13-year-olds. Source Hanushek et al. (2020)

\section{Organization of U.S. Schools}

The picture of U.S. schools is complicated from both a governance and a decision making viewpoint. By the U.S. Constitution, the individual states are the primary government body controlling schools, but this has interacted with the federal government in a variety of ways.

\subsection{Governance}

The U.S. education system is highly decentralized. At the beginning of the 20th Century, there was a federal Office of Education, which was not at the "cabinet rank." Over the past century, there have been several attempts to enhance the federal role. In 1953, the Department of Health, Education, and Welfare was created at the 
cabinet level, and the Office of Education was included along with federal health and welfare functions. In 1979, the Department of Education was created to give cabinet rank to federal education programs, although there have been periodic attempts to disband the department and to demote the status of education at the federal level. Notwithstanding the federal department, the states retain primary responsibility for education programs.

The states have always established separate programs that differ in terms of regulations, finance, local district autonomy, accountability, and ultimately performance. But, as discussed below, they have changed the operations and details of their systems considerably over time.

There was a dramatic consolidation of school districts following WWII. While there were 117,000 districts in 1940, this fell to 18,000 in 1970, and 13, 600 in 2016. There were 133,000 public and private schools in 2016.

Because each of the states is free within broad bounds to set its own policies, it is difficult to implement any common policies across the country. This also makes it difficult even to describe what actions and policies have been undertaken. There are, however, a few notable exceptions outlined below. But there are also common trends.

\subsection{Resources and Expenditures}

The first fact of U.S. schools is that expenditures have been rising very consistentlyat least up to the time of the 2008 recession. Whenever discussions consider the pattern of achievement, they inevitably go to the resources available to the schools. Implicitly if not explicitly the argument inevitably turns to how resources are the answer to any improvements. Table 1 shows the pattern of resources over the past half century, both in terms of the components and of the overall spending per pupil. There were large decreases in pupil-teacher ratios with increases in teacher education. These changes added up to dramatic increases in real spending per pupil—over quadrupling between 1960 and 2016.

Table 1 Public school resources in the United States, 1960-2016

\begin{tabular}{l|l|l|l|l}
\hline & 1960 & 1980 & 2000 & 2016 \\
\hline Pupil-teacher ratio $^{\mathrm{a}}$ & 25.8 & 18.7 & 16.4 & 16.0 \\
\hline$\%$ teachers with master's degree or more & 23.5 & 49.6 & 56.8 & $56.4^{\mathrm{a}}$ \\
\hline $\begin{array}{l}\text { median years teacher of experience } \\
\begin{array}{l}\text { Real expenditure per pupil } \\
\text { (2017-18 } \$ \text { 's) }\end{array}\end{array}$ & 11 & 12 & 14 & n.a \\
\hline
\end{tabular}

n.a. Not available

a Data for 2012

${ }^{b}$ Data on expenditure per pupil are adjusted for inflation using the Consumer Price Index.

Sources U.S. Department of Education (2019) 
It is difficult to argue from these data that the U.S. has overly tight with resources for the schools.

\section{Federal Government Programs and Activities}

The federal government has concentrated its attention on education of poor and disadvantaged students. These programs have been in place for a long time and have generally grown in size over time.

\subsection{The War on Poverty}

In 1965, President Lyndon Johnson declared a "war on poverty.” A major component of this was providing human capital to children from poor families so as to break the cycle of poverty. This compensatory education funding from the federal government, called Title 1 because of its legal foundations, led to a significant increase in funding, one that has grown over time. ${ }^{6}$

Soon after, the federal government initiated Head Start, a preschool program for 3- and 4-year olds from poor families. While never serving all poor children, this program also grew over time so that it served roughly 1 million 3 - and 4-year olds, or roughly one-third of income-eligible students.

Finally, rounding out major programmatic support, the federal government legislated requirements for educating children with both physical and mental special needs in 1975. Support for this program has been split between the federal government and state governments. Over time, enrollment in special education has grown from $8.3 \%$ in 1976 to $13.7 \%$ in 2018. (On average, expenditures for special education students are roughly twice those for other children, although spending varies widely across different disabilities).

This set of federal programs underscores the fact that the U.S. federal government has programs chiefly driven by concerns about equity in education. Each of these programs is designed to support the education of disadvantaged students and is intended to reduce disparities in educational outcomes between children of poor families and children of better off families.

It is also important to note at the outset that funding for these programs was not tied to any specific use of the funds (other than general support for poor children). There are also no regular requirements that programs evaluate performance. As a result, periodic national evaluations of Title 1 compensatory funding and of Head Start ${ }^{7}$

\footnotetext{
${ }^{6}$ For a more complete history of Title 1 and of Head State, see Vinovskis (1999).

${ }^{7}$ The recent randomized evaluation of Head Start found that any positive effects disappeared by grade 3; Puma et al. (2010) and Puma et al. (2012). Note, however, that other studies have found
} 
have not found them to be very successful in terms of increasing the achievement of the targeted students.

\subsection{Desegregation}

In 1954, the U.S. Supreme Court ruled in the court case of Brown v. Board of Education that de jure segregation of schools was unconstitutional. A number of southern states had previously had laws that separated students by race, and this led to an extended period of legal actions designed to desegregate schools.

Segregation of schools goes beyond the laws that were the subject of the Brown decision. Because housing tends to be segregated and because schools are based on local political jurisdictions, there is segregation of schools both because of local school attendance zones within large cities and because of differences in racial composition across school districts.

The Brown decision was followed by continuing legal and policy actions revolving around race and schooling. There was a significant rise in the chance of black students having white classmates through the late 1980s, but then the improvements lessened (Rivkin 2016). The main reason for the decline in exposure was the changing overall composition of U.S. students. White students went from $80 \%$ in 1968 to less than half today. The largest change has been the significant increase in Hispanic students who today make up over one-quarter of the public school population. The black student population has been quite constant since the 1960s at slightly over $15 \%$.

There is no doubt that school desegregation led to better schools for black students. And, as was discussed above, this shows up in reduced achievement gaps between black and white students but a pattern of change that stopped a quarter century ago. ${ }^{8}$ The combination of changing demographics, policy changes, and legal decisions, led to progress that stagnated and imply that this area offers limited possibilities for improvement.

The changing composition of the overall student population does have potential impacts on the aggregate scores for U.S. students. If the immigrant population that makes up the majority of the increase in Hispanic students is also less prepared for school, demographics could influence the trends in achievement that are seen. Some simple calculations that use the changing demographic composition of the U.S. student population suggests, however, that this is not a very powerful force affecting the aggregate scores (Hanushek et al. 2020).

long term impacts of Head Start even if any achievement effects disappeared over time; Currie and Thomas (2000), Johnson and Jackson (2017).

${ }^{8}$ The improvement in outcomes related to desegregation is also found in the evaluation literature. See, for example, Angrist and Lang (2004), Hanushek, Kain, and Rivkin (2009). 


\subsection{Accountability}

School accountability was universalized by the federal government when it passed the No Child Left Behind legislation (NCLB) in 2001. NCLB called for all states to institute annual student testing in grades 3-8 and once in high school, and it required regular reporting of achievement levels by major subgroup (race, poverty, and special education). In reality this was just an extension of the existing policy in a majority of the states.

NCLB set the target that all students had to be proficient (as defined by the individual states) by 2014. There were also intermediate goals that were to be met by each school between 2002 and 2014. If not met, there were various sanctions that were imposed as specified by the federal government: expanded student choice of schools, remedial programs, and ultimately elimination of failing schools.

Over time, it became apparent that few schools would actually meet the proficiency goals. Moreover, resistance to the entire program grew over time. As a result, the NCLB legislation was replaced in 2015 with the Every Student Succeeds Act (ESSA). While this federal law still required annual student testing, most parts of the design of the measurement system, its goals, and its remedial actions were returned to the individual states.

\subsection{The Federal Government Role}

In sum, the federal government in the U.S. has been particularly focused on equity goals and has introduced both funding and regulatory approaches to improving the achievement of students at the bottom of the poverty distribution. As Fig. 3 showed, these policies have not been successful in terms of narrowing achievement gaps.

\section{State Programs and Policies}

The main responsibility for schools in the U.S. resides with the individual states. The states in turn delegate considerable responsibility to individual school districts. (Only Hawaii has a single school district that coincides with the state).

\subsection{School Finance Issues}

The clearest way to see the state role is by observing the pattern of revenue raising over time. As Fig. 4 shows, a century ago almost all revenues were raised by individual localities. But this changed with the local share falling rather steadily. The largest 


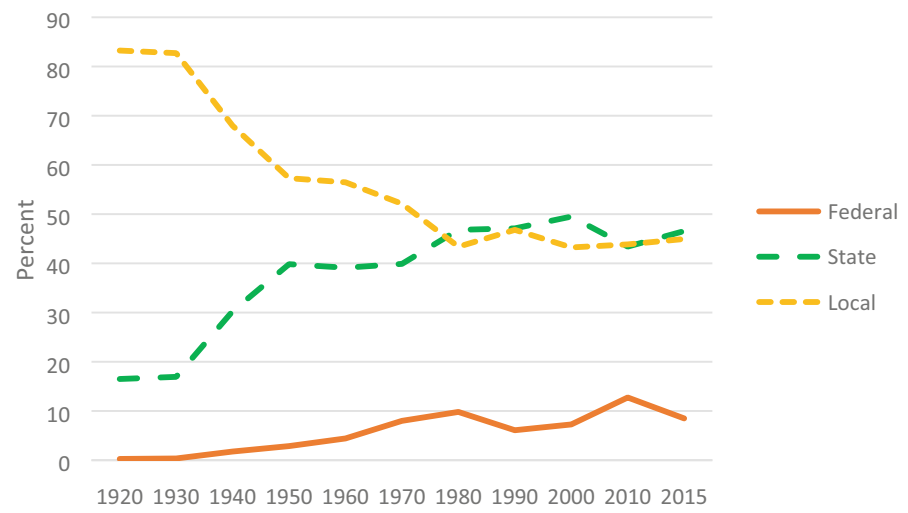

Fig. 4 Sources of U.S. School Revenue. Note Percentage shares of revenues for U.S. public schools. Source U.S. Department of Education (2018)

Table 2 Sources of state school revenue in 2015

\begin{tabular}{l|l|l|l}
\hline & Federal & State & Local \\
\hline Average & $8.5 \%$ & $46.5 \%$ & $45.0 \%$ \\
\hline Minimum & 4.2 & 24.9 & 3.9 \\
\hline Maximum & 14.9 & 90.1 & 66.8 \\
\hline
\end{tabular}

Note This table reflects the range of revenue sources across states in 2015

Source U.S. Department of Education (2019)

changes in revenues came with two policy issues. First was the increase in federal spending that occurred with the War on Poverty in the 1960s leading to an increase of the federal government share to roughly $10 \%$. The second was the beginning of court involvement in spending, starting around 1970 and continuing to today.

The court involvement started with law suits that argued that the funding of schools was not equitable across school districts. Since some districts found it easier to raise funds than others, a number of lawsuits were introduced individually across the states. ${ }^{9}$ Beginning with California in the late 1960s, almost all states have now faced law suits about the pattern of spending. The results of these suits, which sometimes require changes in funding and other times do not, has been a general increase in the state share of spending. The pattern of school revenues does, however, differ noticeably across states. As Table 2 shows, while two-thirds of revenues come from localities in Illinois, only four percent do in Vermont. Federal revenues also vary

\footnotetext{
${ }^{9}$ Local districts disproportionately raise revenues by property taxes. Since localities vary widely in the size of their tax base (which comes from the value of homes plus the value of commercial and industrial property in the district). States will general distribute funds to districts in ways that are inversely related to the local property tax base, but this seldom completely overcomes differences in tax bases. See Hanushek and Lindseth (2009) for a further discussion plus a history of the court involvement.
} 


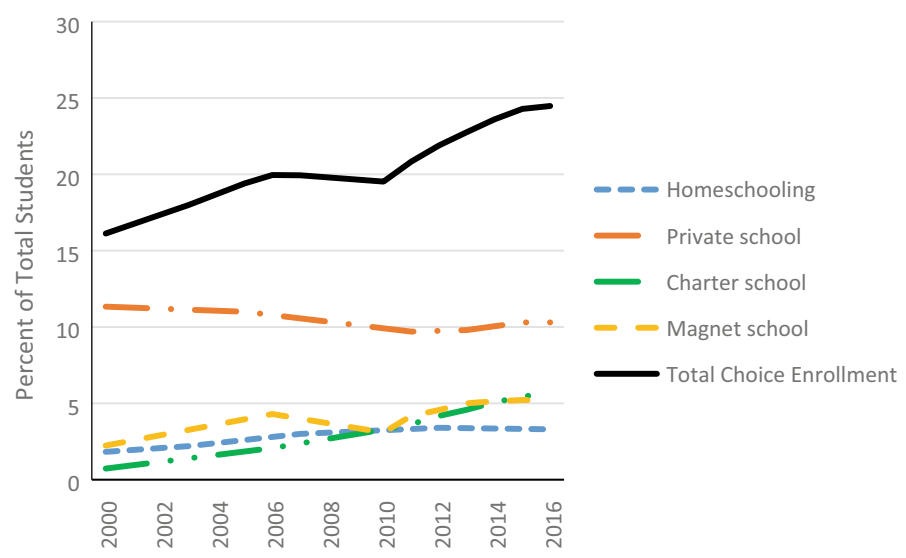

Fig. 5 Students Attending Schools of Choice. Source U.S. Department of Education (2018)

noticeably, depending on the overall level of spending in each state and on the proportion of students from poor families.

A different variety of lawsuits ("adequacy cases" instead of "Equity cases") developed in the late 1980s. These put forward the general argument that, even if state funds were equitably distributed, the level of funding was not adequate to meet the achievement goals of the state. Again, these court cases pursued the general presumption that resources were the problem with the low achievement of students.

Importantly, the source of funds as well as the level of overall spending appears to have little to do with student performance differences across states (Hanushek 2003). Nor does the increase in spending levels relate to the increase in student performance (Hanushek et al. 2012). ${ }^{10}$

\subsection{Choice: Private, Homeschool and Charter Schools}

One thing that has been happening over time is substantial changes in the percentage of students actively choosing what kind of school they attend. As recently as 2000 , $85 \%$ of students went to the traditional public school to which they were assigned (Fig. 5). ${ }^{11}$ By 2016, one-quarter of students made choices of the sector of instruction.

\footnotetext{
${ }^{10}$ Some recent analyses, relying on the estimated impact of court decisions, have argued that extra spending has an impact. These are part of a continuing and unresolved debate. See Jackson, Johnson, and Persico (2016), Lafortune, Rothstein, and Schanzenbach (2018).

${ }^{11}$ Note that these shares of students with choice do not include a number of districts that allow or require students to choose among the traditional public schools. Because all students stay within the traditional public schools, there is no pressure on the school district to try to keep the students. This feature differs from the other forms of choice with the exception of magnet schools. Magnet schools offer specialty curricula (academic, the arts, or other vocational focus), and they offer an alternative to the traditional schools.
} 
Private schooling has been constant at roughly $10 \%$, with the vast majority being religiously based. But charter schools_-public schools that are not controlled by the local districts-have grown significantly (Baude et al. 2020). Perhaps most surprising has been a rising share of students who are home-schooled.

In sum, the U.S. has consistently moved toward more choice of schools. The micro evidence, however, does not show a clear impact of choice programs within the United States (CREDO 2013).

\subsection{Common Core and Curriculum}

One of the major education debates of the past decade has been whether to introduce a common curriculum across the nation. While the federal government cannot impose this, it did help to support the voluntary adoption of the "common core curriculum" across states. Initially over 40 states adopted the common core curriculum, but it became very controversial, and a number of states subsequently repealed it. The state alternatives to the common core, however, often had strong similarities. In the end, however, little evidence suggests superior results with adoption of the common core.

\subsection{The State Government Role}

The states are responsible for the quality of schools. For whatever reason, however, the policy choices have not led to improvements.

\section{Why It Matters}

Existing research shows a very strong and consistent relationship between scores on common standardized tests and economic outcomes. This linkage with future economic well-being motivates the attention to PISA and to alternative approaches to improving student performance. Surprisingly, most policy makers believe that education has important economic outcomes - and yet they often are unwilling to go very far to promote major changes.

\subsection{Economic Growth of Nations}

Economic growth determines the future economic wellbeing of nations, and virtually all empirical studies of the long-run growth of countries have highlighted a role for 
human capital. The early economics literature overwhelmingly employed measures related to school attainment, or years of schooling, to test for the effects of human capital. But, average years of schooling is an incomplete and potentially misleading measure of education when comparing different countries. It implicitly assumes that a year of schooling delivers the same increase in knowledge and skills regardless of the education system. For example, a year of schooling in Peru is assumed to create the same increase in productive human capital as a year of schooling in Japan. It also neglects cross-country differences in the quality of schools and in the strength of family, health, and other influences is a major drawback in such research.

International achievement test scores can be thought of as measures of human capital differences across countries. Indeed, once long run growth rates across countries are related to international test scores, which in the aggregate we call "knowledge capital," three-quarters of the cross-country variation in growth rates can be explained by differences in scores on international math and science tests. (See Fig. 6 and Hanushek and Woessmann 2015a). Moreover, there is reason to believe that this relationship is causal-i.e., if cognitive skills are raised, growth rates will increase (e.g., Hanushek and Woessmann 2012). These estimates indicate that just increasing school attainment without also increasing the amount of learning has no impact.

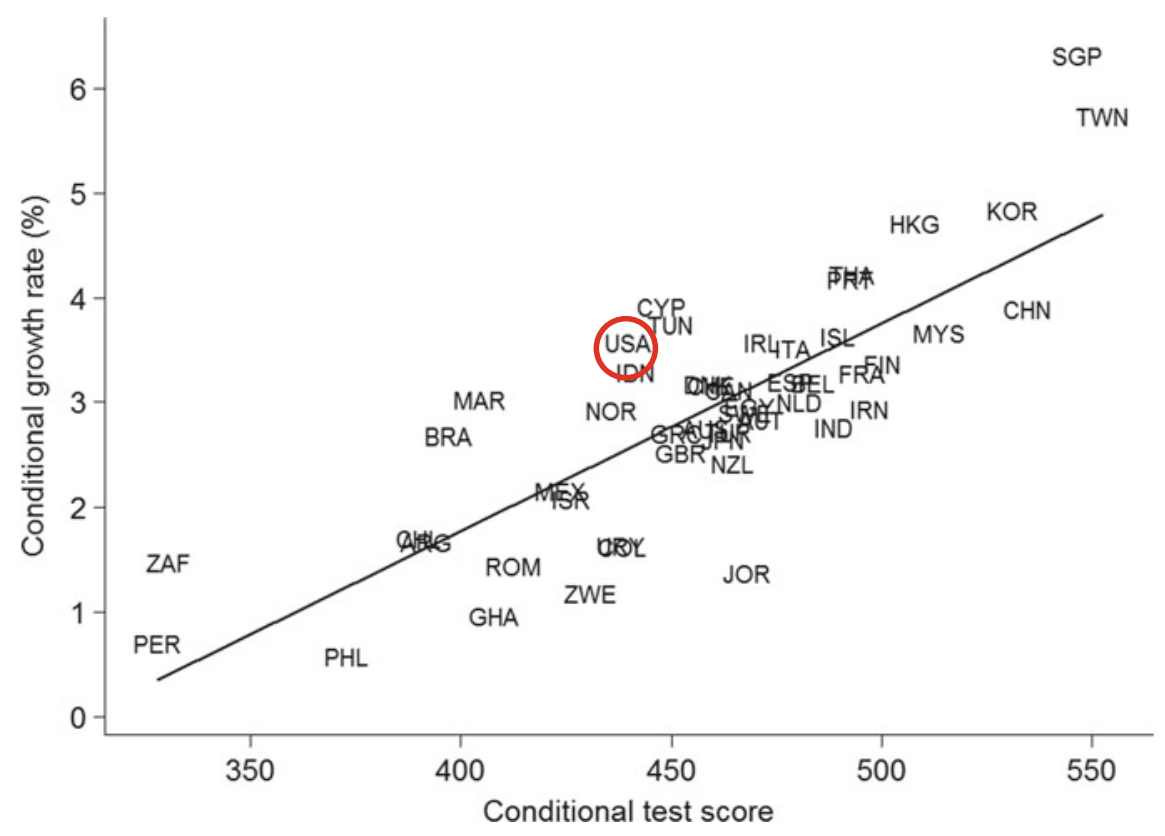

Fig. 6 Knowledge Capital and Long Run Economic Growth (1960-2000). Note: Added variable plot from regression of average annual growth rates in GDP per capita from 1960-2000 on average test scores of nations. The regression includes the level of GPD per capital in 1960 and average years of school attainment in 1960. Source Hanushek and Woessmann (2015a) 
In other words, just getting students through more schooling without ensuring high levels of learning is not an effective policy.

The historical impact on economic growth of differences in test scores is large. One easy way to see the importance of cognitive skills is to project the economic value of school improvement (Hanushek et al. 2013; Hanushek and Woessmann 2015b). For example, consider the estimated impact of bringing just the bottom of the U.S. achievement distribution up to a basic skill level-i.e., a policy similar to the ideas behind U.S. accountability policies. Hanushek and Woessmann (2015b) estimate that, according to historical growth patterns, this would lead to average GDP levels that were $3.3 \%$ higher across the remainder of the century when compared to expected GDP levels with current skill levels. Such increases would be sufficient to deal with most of the fiscal problems suggested for the pension and medical systems.

While politicians may tend to underestimate the importance of education for economic growth, they by all public statements still think that education if extraordinarily important for the nation. Nonetheless, perhaps because it takes time to see the results of any improvements, they are unwilling to make difficult decisions in the short run.

\subsection{Economic Growth of States}

Given the high levels of mobility in the U.S., the work location of somebody might be very different from where the person grew up and went to school. As a result, states do not directly experience all of the results of their school systems. Therefore, while improving schools might be in the national interest, individual states might benefit less and thus might not have strong incentives to invest in better schools. The tension in America between centralized and decentralized education policy has been a pivotal policy issue for decades.

How schools affect state-level measures of economic output is a high priority concern for policy makers (and researchers). In a series of studies, Hanushek et al. (2016, 2017a, b) show that economic growth of individual states, just like nations, is dependent on the quality of the labor force as measured by standardized tests, i.e., the knowledge capital of states. Moreover, the relationship between worker skills and growth at the state level is virtually identical to that found internationally.

Because a majority of students educated in a given state remain in the state when entering the labor force, even with migration, it pays for each state to invest in improved school quality. But since the labor force in each state is comprised of both locally educated workers and workers educated in other states, the largest gains come when all states improve their school quality, as opposed to a single state. 


\subsection{Individual Incomes}

The previous sections focused on the effects of improved school quality on aggregate economic gains at the state and national level. Considerably more research has focused on the relationship between education and individual earnings. Innumerable economic studies show that school attainment affects earnings and income. These studies, pioneered by Mincer (1970, 1974), showed that economic success depends heavily on schooling. Nonetheless, they suffer from many of the same problems described in the previous aggregate studies. In particular, they ignore quality differences in schools, and they ignore sources of skills outside of schools. As demonstrated by the landmark "Equality of Educational Opportunity" report, commonly known as "the Coleman Report," families are very important, as are peers in schools, neighborhood influences, and more (Coleman et al. 1966). An extensive body of research documents the multiplicity of inputs in educational production (e.g., Hanushek 2002).

The alternative, as with the aggregate studies, is to use measured skill from standardized tests to capture the totality of individual skills from families, schools, and other influences. This approach also relates the research more directly to educational policy. It has not been pursued extensively in the past, largely because few data sources combine information on both skills and individual earnings.

Recent international data provide the ability to estimate the economic value to individuals of higher educational achievement. The OECD surveyed random samples of adults age 15-65 across 32 countries in the Program for International Assessment of Adult Competencies (PIAAC). This survey contained information on backgrounds of individuals and their labor market experiences along with giving them a series of standardized tests (see Hanushek et al. 2015, 2017).

Hanushek et al. $(2015,2017)$ estimate the economic returns to greater individual skills. The U.S. has high returns, exceeding those found in almost all of the developed countries that are observed (see Fig. 7). These returns imply that an individual in the U.S. who has skills as defined and measured on international comparative assessments that are one standard deviation above the mean will on average see $28 \%$ higher earnings across the lifetime compared to the median person. But these high returns also imply that somebody one standard deviation below the mean can expect $28 \%$ lower earnings across a lifetime. In other words, the U.S. provides high rewards to acquired skills as measured by standardized tests, but it also severely punishes those with low skills. These estimates are consistent with research about the growing importance of basic cognitive skills from a quarter of a century ago (Murnane et al. 1995).

In sum, a wide range of evidence shows the substantial economic value of improved cognitive skills. This in turn suggests that student test scores merit policy attention. Yet this does not consistently show up in actions. 


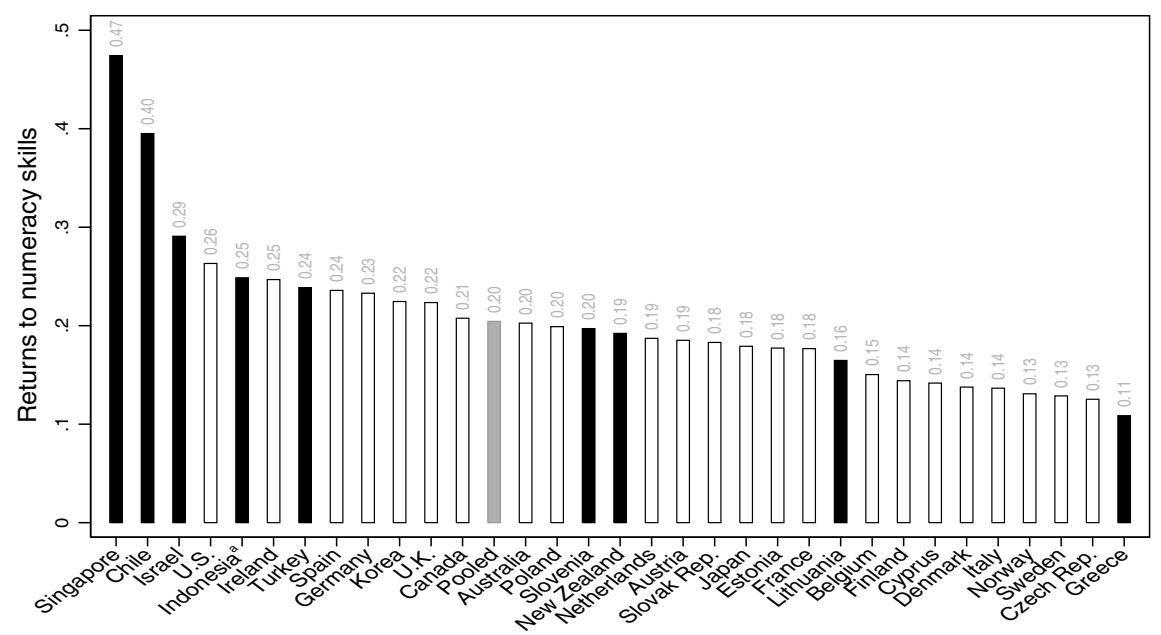

Fig. 7 Estimated Return to Numeracy by Country. Note: Estimates from the Program of International Assessment of Adult Competencies (PIAAC) of the returns to skills across PIAAC countries. Coefficient estimates on numeracy score (standardized to std. dev. 1 within each country) in a regression of log gross hourly wage on numeracy, gender, and a quadratic polynomial in age, sample of full-time employees aged 35-54. Regressions weighted by sampling weights. Hollow bars indicate first-round countries, Black bars indicate second-round countries. *Jakarta only. Source Hanushek et al. (2017)

\section{Why Has the U.S. Done so Well?}

One might ask 'how has the U.S. done so well over the past century when achievement levels are so low?' As seen by the growth chart (Fig. 6), the U.S. has done better than would be expected by its test scores.

Perhaps the most important factor is the favorable economic institutions that support productive use of resources and growth. The United States has generally less governmental intrusion into the operation of economic markets including lower tax rates and less regulation of labor and capital markets. There are strong property rights, and there is quite free movement of labor and capital within the U.S. All of these institutional factors are thought to promote more efficiency and growth.

Of course, these favorable growth institutions may have other implications such as a wider distribution of income or less certain provision of health care. But these are trade-offs made with the implication that growth is stronger than in other countries that choose different kinds of economic and political structures.

Additionally, at least historically the U.S. has had a larger quantity of schooling than other countries in the world, allowing it to substitute quantity for quality. This trade-off includes moving toward high levels of compulsory schooling before most other nations. 
Moreover, by most evaluations, the U.S. has higher quality colleges and universities than are found elsewhere. This university quality has supported an active research and development system and has led to a high level of innovation.

Finally, in terms of factors supporting U.S. success, the United States has been able to attract a highly skilled group of immigrants, thus borrowing from the educational systems elsewhere. For example, of all of the Ph.D's in STEM fields in the U.S., over half are foreign born (Hanson and Slaughter 2019; Hanson et al. 2018).

\section{Will Good Fortune Last?}

The full story developed here is rather straightforward.

First, the U.S. has not done well as measured by international tests. PISA results for 2018 are just the most recent evidence of the mediocre performance of U.S. schools. The overall U.S. performance is around or below the average for the OECD. And, there is no evidence that equity in terms of educational achievement is improving.

Second, this long stasis is not the result of a constant, unchanging schooling system. While decision making in the U.S. is complicated because the 50 states are primary in schooling issues, there have been substantial changes aimed at improving the schools. Funding has increased dramatically. There has been clear school accountability. Parents have more options to choose schools that meet their demands. Many programs and policies are aimed at improving equity in the outcomes of schools including compensatory funding from the federal government, expansion of preschool access and usage, considerable desegregation of schools over the past half century, targeted funding for special education, and added state funding for disadvantaged students. For whatever reasons, these policies have not led to improved school outcomes in the United States.

There is at the same time considerable complacency. After all, with the current schools, the U.S. remains a rich nation with growth that exceeds that in much of the developed world. Isn't it possible simply to continue and to expect good fortune?

Much depends on whether the offsetting forces described above remain effective. Unfortunately, that might not be the case-making it important for the U.S. to depend more fully on its own knowledge capital. The potential for a negative change in fortune appears large enough that the U.S. should work harder at finding ways to improve its schools.

\section{References}

Angrist, J. D., \& Lang, K. (2004). Does school integration generate peer effects? Evidence from Boston's Metco program. American Economic Review, 94(5), 1613-1634.

Baude, P. L., Casey, M., Hanushek, E. A., Phelan, G. R., \& Rivkin, S. G. (2020). The evolution of charter school quality. Economica, 87(345), 158-189. 
Coleman, J. S., Campbell, E. Q., Hobson, C. J., McPartland, J., Mood, A. M., Weinfeld, F. D., \& York, R. L. (1966). Equality of educational opportunity. Washington, D.C.: U.S. Government Printing Office.

CREDO. (2013). National charter school study 2013. Stanford, CA: Center for Research on Education Outcomes, Stanford University.

Currie, J., \& Thomas, D. (2000). School quality and the longer-term effects of head start. Journal of Human Resources, 35(4), 755-774.

Hanson, G. H., Kerr, W. R., \& Turner, S. (Eds.). (2018). High-skilled migration to the United States and its economic consequences. Chicago: University of Chicago Press.

Hanson, G. H., \& Slaughter, M. J. (2019). High-skilled immigration and the rise of stem occupations in US employment. In C.R. Hulten, \& V.A. Ramey (Eds.), Education, skills, and technical change: Implications for future US GDP Growth (pp. 465-494). Chicago: University of Chicago Press.

Hanushek, E. A. (2002). Publicly provided education. In A. J. Auerbach \& M. Feldstein (Eds.), Handbook of public economics (Vol. 4, pp. 2045-2141). Amsterdam: North Holland.

Hanushek, E. A. (2003). The failure of input-based schooling policies. Economic Journal, 113(485), F64-F98.

Hanushek, E. A., Kain, J. F., \& Rivkin, S. G. (2009). New Evidence about Brown V. Board of Education: The complex effects of school racial composition on achievement. Journal of Labor Economics 27(3), 349-383.

Hanushek, E. A., \& Lindseth, A. A. (2009). Schoolhouses, courthouses, and statehouses: Solving the funding-achievement puzzle in America's public schools. Princeton, NJ: Princeton University Press.

Hanushek, E. A., Peterson, P. E., Talpey, L. M., \& Woessmann, L. (2020, February). Long-run trends in the U.S. Ses-achievement Gap. NBER Working Paper No. 26764. Cambridge, MA: National Bureau of Economic Research.

Hanushek, E. A., Peterson, P. E., \& Woessmann, L. (2012). Is the United States catching up? International and state trends in student achievement. Education Next, 12(4), 24-32.

Hanushek, E. A., Peterson, P. E., \& Woessmann, L. (2013). Endangering prosperity: A global view of the American school. Washington, DC: Brookings Institution Press.

Hanushek, E. A., Ruhose, J., \& Woessmann, L. (2016). It pays to improve school quality: States that boost student achievement could reap large economic gains. Education Next, 16(3), 16-24.

Hanushek, E. A., Ruhose, J., \& Woessmann, L. (2017a). Economic gains from educational reform by US states. Journal of Human Capital 11(4), 447-486.

Hanushek, E. A., Ruhose, J., Woessmann, L. (2017b). Knowledge capital and aggregate income differences: Development accounting for U.S. states. American Economic Journal: Macroeconomics 9(4), 184-224.

Hanushek, E. A., Schwerdt, G., Wiederhold, S., \& Woessmann, L. (2015). Returns to skills around the World: Evidence from PIAAC. European Economic Review, 73, 103-130.

Hanushek, E. A., Schwerdt, G., Wiederhold, S., \& Woessmann, L. (2017). Coping with change: International differences in the returns to skills. Economic Letters 153, 15-19.

Hanushek, E. A., \& Woessmann, L. (2011). The economics of international differences in educational achievement. In E.A. Hanushek, S. Machin, \& L. Woessmann (Eds.), Handbook of the economics of education (Vol. 3, pp. 89-200), Amsterdam: North Holland.

Hanushek, E. A., \& Woessmann, L. (2012). Do better schools lead to more growth? Cognitive skills, economic outcomes, and causation. Journal of Economic Growth, 17(4), 267-321.

Hanushek, E. A., \& Woessmann, L. (2015a). The knowledge capital of nations: Education and the economics of growth. Cambridge, MA: MIT Press.

Hanushek, E. A., \& Woessmannm, L. (2015b). Universal basic skills: What countries stand to gain. Paris: Organisation for Economic Co-operation and Development.

Jackson, C. K., Johnson, R. C., \& Persico, C. (2016). The Effects of school spending on educational and economic outcomes: Evidence from school finance reforms. Quarterly Journal of Economics, 131(1), 157-218. 
Johnson, R. C., \& Kirabo Jackson, C. (2017, June). Reducing inequality through dynamic complementarity: Evidence from head start and public school spending. NBER Working Paper No. 23489. Cambridge, MA: National Bureau of Economic Research.

Lafortune, J., Rothstein, J., \& Schanzenbach, D. W. (2018). School finance reform and the distribution of student achievement. American Economic Journal: Applied Economics, 10(2), $1-26$.

Mincer, J. (1970). The distribution of labor incomes: A survey with special reference to the human capital approach. Journal of Economic Literature, 8(1), 1-26.

Mincer, J. (1974). Schooling, experience, and earnings. New York: NBER.

Murnane, R. J., Willett, J. B., \& Levy, F. (1995). The growing importance of cognitive skills in wage determination. Review of Economics and Statistics, 77(2), 251-266.

Puma, M., Bell, S., Cook, R., \& Heid, C. (2010). Head start impact study: Final report. Washington, DC: Administration for Children and Families (January).

Puma, M., Bell, S., Cook, R., Heid, C., Broene, P., Jenkins, F., Mashburn, A., \& Downer, J. (2012). Third grade follow-up to the Head Start impact study final report. Washington, DC: Office of Planning, Research and Evaluation, Administration for Children and Families, U.S. Department of Health and Human Services.

Rivkin, S. G. (2016). Desegregation since the Coleman Report: Racial composition of schools and student learning. Education Next, 16(2), 29-37.

U.S. Department of Education. (2018). Digest of education statistics, 2017. Washington, DC: National Center for Education Statistics.

U.S. Department of Education. (2019). Digest of education statistics 2018. Washington, DC: National Center for Education Statistics.

Vinovskis, M. A. (1999). Do federal compensatory education programs really work? A brief historical analysis of Title I and Head Start. American Journal of Education, 107(3), 187-209.

Eric Hanushek is the Paul and Jean Hanna Senior Fellow at the Hoover Institution of Stanford University. He is a recognized leader in the economic analysis of education issues, and his research has had broad influence on education policy in both developed and developing countries. He is the author of numerous widely-cited studies on the effects of class size reduction, school accountability, teacher effectiveness, and other topics. He was the first to research teacher effectiveness by measuring students' learning gains, which formed the conceptual basis for using value-added measures to evaluate teachers and schools, now a widely adopted practice. His recent book, The Knowledge Capital of Nations: Education and the Economics of Growth summarizes his research establishing the close links between countries' long-term rates of economic growth and the skill levels of their populations. His current research analyzes why some countries' school systems consistently perform better than others. He has authored or edited twenty-four books along with over 250 articles. He is a Distinguished Graduate of the United States Air Force Academy and completed his Ph.D. in economics at the Massachusetts Institute of Technology. 
Open Access This chapter is licensed under the terms of the Creative Commons Attribution 4.0 International License (http://creativecommons.org/licenses/by/4.0/), which permits use, sharing, adaptation, distribution and reproduction in any medium or format, as long as you give appropriate credit to the original author(s) and the source, provide a link to the Creative Commons license and indicate if changes were made.

The images or other third party material in this chapter are included in the chapter's Creative Commons license, unless indicated otherwise in a credit line to the material. If material is not included in the chapter's Creative Commons license and your intended use is not permitted by statutory regulation or exceeds the permitted use, you will need to obtain permission directly from the copyright holder.

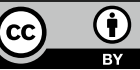

